\title{
Type of Information Resources and Feedback Facilities for Corporate Social Responsibility Related Issues on Corporate Websites in Indonesia
}

\author{
Dr. Ati Harmoni (Gunadarma University, Indonesia) \\ Hanum Putri Permatasari (Gunadarma University, Indonesia)
}

\begin{abstract}
Companies in Indonesia have made use of the official website as a medium to convey important information, including corporate social responsibility (CSR) programs to stakeholders. This study was conducted to look at the type of resources and means of feedback available on the company's website in Indonesia in terms of disclosure of CSR issues. Survey conducted on forty five (45) companies' included in the LQ45 index period 2013. A content analysis methodology was used and applied to the corporate websites of the 45 companies studied. Two type of analysis established: the content category served to identify the issues included in CSR and the information resources and feedback resources. Ten values corresponding to issues related to CSR were identified. Results showed that more companies are using information expositive form of text, images and graphics. Expositive sources rarely used form is video, while the interactive resources are used only for specific information by some companies. Means of public feedback on the web is a general email to all types of information. Other mean of feedback are telephone and facsimile.
\end{abstract}

\section{Introduction}

Currently the company is not only required to implement CSR programs in earnest but also must be able to communicate it to all stakeholders. Developments in information technology and computers, including the Internet and the World Wide Web facility (WWW), has provided a variety of media options to companies to disclose CSR programs and enhance its relationships with stakeholders. It is also because the stakeholders affected by the company, directly or indirectly, including the general public is entitled to know the aspects that come into contact with their lives. There is now also heightened demand for better corporate citizenship and greater transparency in many developing countries. However, little is known or understood about the concept and practice of CSR in these emerging markets.

Research on the public company in Indonesia shows that mining companies included in the index Bisnis27/Sri-Kehati/LQ45 have had official website (Ati, 2011). While previous research on companies operating in basic industries and chemicals revealed that on its official website, the company has demonstrated attention to the importance of CSR information to the public, by putting CSR on the high hierarchy menu. On the other hand, the use of which expositif resources such as text, images, pictures, and graphics just shows that the web is still a one -way (unidirectional) and have shown a low interactivity with just providing feedback means limited (Ati, 2009).

Premised on the importance of CSR communication and the critical role of the Internet in contemporary corporate communication, this study examines the extent and characteristics of Web-based CSR communication undertaken by the companies in Indonesia. This study was conducted to provide a wider picture of the use of the official website as a means of communication of CSR by companies operating in Indonesia. The study focuses on the type of resources and sources of feedback available on the company's website in Indonesia in terms of disclosure of CSR issues. Information resources and feedback resources to show how important the company saw its stakeholders and how companies dialogue with them.

\section{Background}

There are several definitions regarding CSR, the following ones are examples of established meanings. The World Business Council stated that "Corporate Social Responsibility is the continuing commitment by business to behave ethically and contribute to economic development while improving the quality of life of the workforce and their families as well as of the local community and society at large" (Holme/Watts, 2000). The European Commission defines it in their 'Grünbuch' as "a concept whereby companies integrate social and environmental concerns in their business operations and in their interaction with their stakeholders on a voluntary basis" (European Commission, 2010). The second definition clearly states that social and environmental issues are key components of CSR. When expanding these by incorporating the economic scope, the three dimensions of CSR can be defined.

CSR communication via the corporate Web has been a direct offshoot of the digital revolution. Esrock and Leichty (1999) noted that corporate Websites allow companies to engage in multi-stakeholder dialogue, a practical challenge of CSR communication. The Web also offers organizations the opportunity to design 
messages that do not have to follow the dictates of gatekeepers as with print and electronic media. Hence, Web pages are available option for corporations to set and present an agenda on CSR.

Whether corporations are doing a good job of fully exploiting the Internet's potential for their CSR communication is debatable. One of the earliest related studies (Esrock \& Leichty, 1998) found that even though $90 \%$ of Fortune 500 companies had Web pages (of which $82 \%$ addressed at least one CSR issue), corporate Web sites were still not being used to their full potential as a medium for communicating socially responsible activities.

According to a 2004 CSR Online Survey of Financial Times Stock Exchange companies, although many companies included CSR information on their Web site, "all too often, CSR material is hidden in hard-to-reach places, or presented as huge PDF downloads" (Coope, 2004). The study of CSR communication on the Internet has started to receive attention in the Asian context (e.g., Fukukawa \& Moon, 2004; Thompson \& Zakaria, 2004; Welford, 2004).

Indonesia has become the first nation in the world to introduce mandatory legal requirements for corporations to implement corporate social responsibility (CSR) reporting based on Law No 40 in 2007 regarding Limited Liability Companies (Rosser and Edwin, 2010). According to this law, all corporations that operate in Indonesia's natural resources sector or that have business activities related to natural resources must implement CSR, especially in relation to environmental responsibility, called corporate social and environmental responsibility (CSER). The CSER includes reporting activities as well as the funding to cost the activities taken from the companies' budget.

The motivation of corporations to invest on CSR in Indonesia varies, but almost all are claiming the same type of problem, namely internal and external ones. The internal problems come within the corporations, for example internal management of the firms that are related to the inherent values underlying the business activities. Other problems are the lack of CSR expertise in the firms, unsupportive local and management structure and attitude, and the difficulties in adopting operational standards. The external ones driven from outside the corporations, such as the external environment which are not reachable by the firms, government related issues, customer and community behavior in general, as well as the influence of civil society organizations (Koestoer, 2007).

\section{Methodology}

Object of this study are the official web public companies operating in Indonesia. Criteria for selecting companies for this research is a company listed on the Indonesia Stock Exchange (IDX) and included in the LQ45 the period February - July 2013 (Register issued on January 25, 2013, http://www.idx.co.id). LQ45 Index is a stock price index issued by the Indonesia Stock Exchange which contains 45 stocks that meet the criteria of fundamental and technical or transactions liquidity.

\begin{tabular}{|l|l|}
\hline CSR Issues & Definition \\
\hline Company Profile & $\begin{array}{l}\text { Explanation of the enterprise's views, values, and corporate strategy. Presentation of } \\
\text { the company's property, structure, and legal form; divisions, subsidiaries and } \\
\text { countries with which the enterprise operates. Explanation of results }\end{array}$ \\
\hline Goods and Services & $\begin{array}{l}\text { Explanation of the enterprise's products, services, and brands from a corporate } \\
\text { perspective and not from a commercial one (type of products, raw materials, } \\
\text { manufacture systems, etc.) }\end{array}$ \\
\hline Employees and HR & $\begin{array}{l}\text { Declarations and explanations of its systems of contract, promotion, evaluation, and } \\
\text { dismissal. Declarations and explanations about human rights in the enterprise } \\
\text { (children labour, discrimination...) }\end{array}$ \\
\hline Economic Action & $\begin{array}{l}\text { Declarations and actions related to the economic impact of the enterprise in its local, } \\
\text { regional, national, and supranational environment }\end{array}$ \\
\hline Social Action & Declarations and actions related to the enterprise's involvement in social issues \\
\hline Environmental Action & $\begin{array}{l}\text { Declarations and actions related to the enterprise's involvement in environmental } \\
\text { issues }\end{array}$ \\
\hline Corporate Governance & $\begin{array}{l}\text { Declarations and explanations of the enterprise's transparency, compromises in the } \\
\text { governance of the company. Explanation of the structure of power, remunerations, } \\
\text { responsibilities, government departments, etc. }\end{array}$ \\
\hline Corporate Ethics & $\begin{array}{l}\text { Declarations and explanations about the enterprise's ethical compromises in relation } \\
\text { with the business and its groups of public }\end{array}$ \\
\hline External criteria & $\begin{array}{l}\text { Declarations and explanations about the interests, importance, and linking of the } \\
\text { groups of public with the enterprise }\end{array}$ \\
\hline
\end{tabular}

Table 1. Issues of CSR. Source: Capriotti and Moreno (2007) 
A content analysis methodology was used and applied to the corporate websites of the 45 companies studied. Two type of analysis established: the content category served to identify the issues included in CSR and the information resources and feedback resources. Ten values corresponding to issues related to CSR (Table 1) were identified.

The information resources category allows the identification of the different resources used to present the information on CSR. Two types of resources were recognized. (1) Expositive resources are those that allow the dissemination of information, with the visitor eminently passive and receptive. These types of resources are differentiated as graphic (written text and fixed images, photos, and graphics) or audiovisual (audio and video). (2) Interactive resources are those that permit information to be obtained through active interaction, with a mainly active and participative visitor. These include hypertexts, interactive graphics, charts, and similar resources. The feedback resources category facilitates the identification of the systems available on corporate websites for visitors to ask questions, give opinions, or assess the CSR issues. Three types of possible forms of feedback were laid out: (1) general email to the company; (2) specific email linked to CSR issues; (3) other forms of feedback (questionnaires, chats, forums, blogs, etc.) that allow an assessment of or opinions on any of the issues on CSR. The latter type implies an active incentive resource to generate opinions and assessments from visitors.

\section{Findings}

Table 2 shows a list of names and addresses of companies. Of the 45 companies studied, all (100\%) has a web-accessible by Internet users.

\begin{tabular}{|c|c|c|c|c|c|}
\hline Name & Web Address & Name & Web Address & Name & Web Address \\
\hline AALI & www.astra-agro.co.id & BSDE & www.bsdcity.com & JSMR & www.jasamarga.com \\
\hline ADRO & www.adaro.com & BUMI & www.bumiresources.com & KLBF & www.kalbe.co.id \\
\hline AKRA & www.akr.co.id & BWPT & www.bwplantation.com & LPKR & www.lippokarawaci.co.id \\
\hline ANTM & www.antam.com & CPIN & www.cp.co.id & LSIP & www.londonsumatra.com \\
\hline ASII & www.astra.co.id & EXCL & www.xl.co.id & MAIN & www.malindofeedmill.com \\
\hline ASRI & www.alam-sutera.com & GGRM & www.gudanggararmtbk.com & MAPI & www.map-indonesia.com \\
\hline BBCA & www.bca.co.id & GIAA & www.garuda-indonesia.com & MNCN & www.mnc.co.id \\
\hline $\mathrm{BBNI}$ & www.bni.co.id & HRUM & www.harumenergy.com & PGAS & www.pgn.co.id \\
\hline BBRI & www.bri.co.id & ICBP & www.indofoodcbp.com & PTBA & www.ptba.co.id \\
\hline BBTN & www.btn.co.id & IMAS & www.indomobil.com & SMCB & www.holcim.co.id \\
\hline BDMN & www.danamon.co.id & INCO & www.valeindonesia.co.id & SMGR & www.semengresik.com \\
\hline BHIT & $\begin{array}{l}\text { www.bhakti- } \\
\text { investama.com }\end{array}$ & INDF & www.indofood.com & SSIA & www.suryainternusa.com \\
\hline BKSL & www.sentulcity.co.id & INDY & www.indikaenergy.com & TLKM & www.telkom-indonesia.com \\
\hline BMRI & www.bankmandiri.co.id & INTP & www.indocement.co.id & UNTR & www.unitedtractors.com \\
\hline BMTR & www.mediacom.co.id & ITMG & www.itmg.co.id & UNVR & www.unilever.co.id \\
\hline
\end{tabular}

Table 2. Website of the Companies

\subsection{Issues of CSR}

The Internet has become an essential space through which to diffuse information about corporate responsibility. All of the companies the LQ45 present information about CSR on their webpages. Specific CSR menu also have an important presence on the corporate Web pages of the LQ45companies. Of these, 66.7\% have a specific menu, and $33.3 \%$ do not. Of the enterprises with a specific menu, the majority call it "Corporate Social Responsibility" or "CSR" (42.2\%), followed by "Social Responsibility" (8.9\%). Three companies use "Sustainable Development" (6.7 \%) and only one enterprise calls the menu "Sustainability" (2.2\%).

\begin{tabular}{lcc}
\hline Type of Information Resources & Total & Percentage \\
\hline Menu & 24 & $53 \%$ \\
Submenu & 9 & $20 \%$ \\
Sub Submenu & 1 & $2 \%$ \\
Subdomain & 1 & $2 \%$ \\
Not Available & 10 & $22 \%$ \\
\hline
\end{tabular}

Table 3. Website of the Companies

CSR related issues on their websites are $53 \%$ available on specific menu, $20 \%$ in submenu, $2 \%$ in sub submenu, $2 \%$ in subdomain and $22 \%$ did not provide in specific menu, nor submenu, sub submenu and subdomain (Table 3). 
The 10 CSR issues presented on the corporate websites are not homogeneous (Table 4). The most present and relevant issues are those linked to the presentation of the general characteristics of the company (corporate profile) and of its products and services. This reinforces the idea of the self-presentation function of corporate websites. These issues have an eminently descriptive and informative approach and are more commercial in perspective, rather than allowing an ethical valuation or an appraisal of the company's compromises in its production and marketing activities.

It must also be remarked that the issue of economic action does not have the prominence given to corporate profile and products and services. However, issue with a high presence is employee and human resources, and social action. Finally, a remarkable fact is that the issue of corporate ethics does not get special attention on the corporate websites.

\begin{tabular}{lc}
\hline Issues of CSR & Presence (in \%) \\
\hline Company Profile & 100 \\
Goods and Services & 100 \\
Employees and HR & 82.2 \\
Economic Action & 48.9 \\
Social Action & 62.2 \\
Environmental Action & 53.3 \\
Corporate Governance & 53.3 \\
Corporate Ethics & 37.8 \\
Public Relations & 53.3 \\
External Criteria & 48.9 \\
\hline
\end{tabular}

Table 4. Presence of CSR Issues on Corporate Website

\subsection{Resources used to present the information on CSR}

As for the resources used to present the information on CSR, the results show a clear predominance of the socalled "expositive" resources over the "interactive" resources (Figure 1).

Graphic resources are the main resources that are used to transmit information on the CSR issues (used by $96 \%$ of the companies). The use of audiovisual resources can also be considered highly significant (used by $11 \%$ of the companies), because the use of these resources on the Internet is troublesome (it slows website surfing). Interactive resources are used by $9 \%$ of the companies. These resources are typical of and inherent in the Internet, and are what make it different from other media. Hence, we can declare that there is little significant presence of interactive resources for CSR issues on the websites studied.

As can be observed in Table 5, the only areas for which a suitable combination of the communication resources available (graphic, audiovisual and interactive) is used are corporate profile (a presentation of the company in general terms) and products and services, which clearly shows the importance and relevance of these sections within the websites, as compared with other CSR issues.

\begin{tabular}{llccc}
\hline & & \multicolumn{3}{c}{ Information resources (in \%) } \\
\cline { 3 - 4 } No & Issues & \multicolumn{2}{c}{ Expositive } & Interactive \\
\cline { 2 - 4 } 1 & Company Profile & 96 & 11 & 9 \\
2 & Products and Services & 93 & 2 & 4 \\
3 & Employees and HR & 82 & 0 & 2 \\
4 & Economic Action & 49 & 0 & 2 \\
5 & Social Action & 62 & 2 & 2 \\
6 & Environmental Action & 53 & 0 & 2 \\
7 & Corporate Governance & 53 & 0 & 2 \\
8 & Corporate Ethics & 38 & 0 & 4 \\
9 & Public Relations & 53 & 0 & 2 \\
10 & External Criteria & 49 & 0 & 0 \\
\hline
\end{tabular}

Table 5. Resources of Information

\subsection{Feedback resources used with CSR information}

With regard to the resources available to facilitate feedback (Figure 1), 82.2\% of the companies in the LQ45 provided an email address whereas $91.1 \%$ had "traditional" feedback instrument for general information from website.

With regard to email, only $48.8 \%$ of the companies have a specific email address for some of the concrete CSR issues in the corresponding sections while all companies that had email given a general email address, which is for the common use of all sections on the website. The high incidence of the use of email addresses 
hides two relevant deficiencies. Firstly, there is little stimulus for specific feedback on the concrete CSR issues, as the specific email addresses are a tool almost exclusively offered to shareholders and investors and for economic-financial matters (usually found in the areas devoted to financial, shareholder, or investor information). Secondly, an assessment of the information available on the websites is not favourable, as no evaluation tools (such as interactive opinion polls, opinion forms, etc.) are provided, nor are there interactive feedback tools (such as chat rooms, forums, blogs, etc.) that would allow visitors to interact with the companies or with other people about the CSR topics in real time.

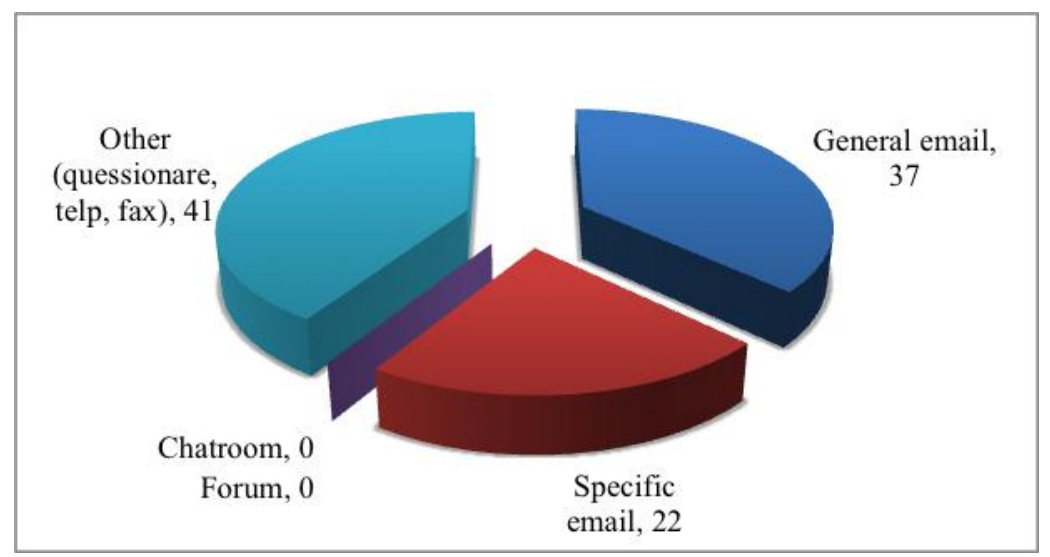

Figure 1. Feedback Resources

\section{Conclusion}

The study concluded that corporate websites in Indonesia have type of information resources and feedback facilities for CSR related issues. Results showed that more companies are using information expositive form of text, images and graphics. Expositive sources rarely used form is video, while the interactive resources are used only for specific information by some companies. Means of public feedback on the web is a general email to all types of information. Other mean of feedback are telephone and facsimile. The analysis result showed the companies that use specific menu about CSR on their websites (66.7\%) and 33.3\% do not. Name of the specific menu were "Corporate Social Responsibility" "Social Responsibility", "Sustainability Development", "Sustainability", and other.

With regard to the resources available to facilitate feedback, $82.2 \%$ of the companies in the LQ45 provided an email address whereas $91.1 \%$ had "traditional" feedback instrument for general information from website. Only $48.8 \%$ of the companies have a specific email address for some of the concrete CSR issues in the corresponding sections while all companies that had email given a general email address, which is for the common use of all sections on the website.

\section{References}

- Ati Harmoni, 2009.’InteraktivitasIsu CSR pada Laman ResmiPerusahaan. Studipada PT IndocementTunggalPrakarsaTbk."'in ProceedingofSeminarNasional Teknologi Informasi (SNATi), FTI UII, Yogyakarta

- $\quad$ Ati Harmoni, 2010.’Pemanfaatan Laman ResmiSebagai Media PengungkapanTanggungJawabSosialPerusahaan/CSR padaPerusahaan di Indonesia", Jurnal Ilmiah Ekonomi Bisnis, 1, No 15.

- Capriotti, P. dan A. Moreno, 2007. "Corporate Citizenship and Public Relations: The Importance and Interactivity of Social Responsibility Issues on Corporate Websites.”Public Relations Review, 33, pp.84-91

- Coope, R., 2004. "Seeing the "Net potential” of online CSR communications. "Corporate Responsibility Management, 1, pp.20-25.

- European Commission, 2002. Sustainable and responsible business, Corporate Social Responsibility (CSR), URL:http://ec.europa.eu/enterprise/policies/sustainable-business/corporate-socialresponsibility/ index_en.htm.

- $\quad$ Esrock, S. and Leicthty, G, 1999. "Corporate World Wide Web pages: Serving the news media and other publics. "Journalism and Mass Communication Quarterly, 76, pp.456-467.

- $\quad$ Esrock, S. and Leicthty, G, 1998. "Social Responsibility and Web Pages: Self Presentation or Agenda Setting?”, Public Relation Review, 24(3), pp.305-319 
- $\quad$ Fukukawa, K., \& Moon, J., 2004. “A Japanese model of corporate social responsibility? A study of website reporting. "Journal of Corporate Citizenship, 16, 45-59.

- Holme, R. and Watts, P., 2000. Corporate Social Responsibility: Making good business sense, URL: http://www.wbcsd.org/web/publications/csr2000.pdf, access 9 April 2014

- Koestoer, Yanti T., 2007. “Corporate Social Responsibility in Indonesia. Building internal corporate values to address challenges in CSR implementation." Paper presented at Seminar on Good Corporate and Social Governance in Promoting ASEAN's Regional Integration, Asian Secretariat, Jakarta.

- $\quad$ Rosser, A. \& Edwin, D., 2010. “The politics of corporate social responsibility in Indonesia.”The Pacific Review, 23[1], 1-22

- $\quad$ Thompson, P. and Zakaria, Z. 2004. Corporate social responsibility reporting in Malaysia progress and prospects. Journal of Corporate Citizenship, 13 (Spring), pp.125-136. 